\title{
Microbial load and safety of paper currencies from some food vendors in Jimma Town, Southwest Ethiopia
}

\author{
Gosa Girma, Tsige Ketema and Ketema Bacha*
}

\begin{abstract}
Background: Paper currency is used for every type of commerce and plays an important role in the life of human beings. However, the combination of its widespread use and constant exchange make paper currency a likely agent for disease transmission. Thus, the aim of this study was to evaluate the microbial load and safety of Ethiopian paper currencies collected from some food vendors in Jimma town.

Methods: Standard microbiological methods were used for the enumeration of various microbial groups, isolation and characterization of pathogenic bacteria and their growth potential in selected weaning foods. A total of 100 samples of Ethiopian paper currencies, consisting of five denominations, from street food venders, hotels and cafeterias in Jimma town were collected aseptically. Sterile cotton swabs moistened with buffered peptone water solution were used for swabbing and the swabs were separately soaked into $10 \mathrm{ml}$ sterile buffered peptone water solution.
\end{abstract}

Results: Mean microbial counts of Aerobic mesophilic bacteria, Staphylococci, Enterobacteriaceae, coliforms and Aerobic bacterial spores were $\left(\log \mathrm{CFU} / \mathrm{cm}^{2}\right) 6.32,4.43,3.14,2.98$ and 3.78, respectively. However, mean counts of Yeasts and Moulds were below detectable levels. There was statistically significant variation $(p<0.05)$ among the mean counts of microbes isolated from samples of paper currencies. The predominantly isolated microbial groups were Staphylococcus spp. (34.06\%) followed by Bacillus spp. (31.88\%), Enterobacteraceae (13.39\%), Micrococcus spp. (9.55\%) and Streptococcus spp. (9.03\%). Overall, $25 \%$ and 10\% of the samples were positive for S. aureus and Salmonella spp, respectively. In challenge study, Salmonella spp. and S. aureus reached the infective dose within 12 to 18 hours of inoculation.

Conclusion: Thus, paper currencies could be considered as one of the possible vehicles for transmission of disease causing microorganisms. Poor handling practices and personal hygiene of the food vendors could contribute to the observed microbial counts. Thus, it calls for awareness development on the potential risks associated with poor handling of paper currencies at all level of the food establishments.

Keywords: Ethiopia, Food vendors, Jimma, Microbial load, Microbial safety, Paper currency

\section{Background}

Trade has been practiced by human from time immemorial and money is an indispensable part of it since its introduction in China approximately $1000 \mathrm{AD}$ [1]. We use money as a measuring unit in pricing a transaction, offer it as a medium for exchange of goods and services, settlement of debts, for deferred payments in economic activities and make it a store of value for our savings.

\footnotetext{
*Correspondence: ketemabacha2002@yahoo.com

Department of Biology, Jimma University, College of Natural Sciences, Jimma,
} Ethiopia

\section{Biomed Central}

When used as medium of exchange, paper currencies could be handled under unhygienic conditions and possibly contaminated with different microbes [2,3], making it a prime multiplication medium for various microorganisms and could constitute a major health hazard [4].

Many people do not care to the level of cleanness of their fingers when handling money and pick paper currencies with contaminated hands, leading to the contamination of paper currency notes with microorganisms [5]. Furthermore, market men and women squeeze paper currencies and put them into their dirty pockets. Meat 
sellers in slaughter houses and at market places usually collect money from buyers with hands contaminated with blood and animal wastes [5,6]. Such money handling habits can introduce microbes to the notes. In most parts of the world, it is believed that the simultaneous handling of food and money/currency/ contributes to the incidence of food-related public health incidents [7]. Data accumulated during the last 20 years indicate that pathogens on currency notes could represent a potential cause of foodborne illness [8]. Evidently, many food outlets rely heavily on paper currencies for exchange with high frequency of contact between the currencies and foods [9] risking the safety of consumers [10].

According to reports made from several studies, many bacterial groups such as Citrobacter sp., Mycobacterium lepirae, Salmonella sp., Escherichia coli, Staphylococcus aureus, Klebsiella sp, Streptococcus spp. and Pseudomonas aeroginosa were found associated with paper currency notes $[3,11]$. Paper currencies were also reported contaminated with fungi including Aspergillus niger, A. flavus, A. paraziticus, Candida spp. Penicillium spp. and Rhizopus spp., Alternaria tenuis, Trichoderma spp., Fusarium spp., and Sporotrichum spp. [3,8,11-14].

Microbial contaminants of paper currencies could be from several sources including counting machine, atmosphere, storage environment, usage, handling or production $[15,16]$. Moreover, the contamination of currency notes could be traced to dust, soil, water, body of currency handlers (such as hand, skin, and wounds). Furthermore, many people tongue-wet their fingers when counting money thereby, contaminating their fingers as well as currency notes [2].

Though several studies reported on the level of microbial contamination of paper currencies from different parts of the world including Africa, to-date to the authors' knowledge there was no report on its status from Ethiopia. Therefore, the purpose of this study was to evaluate the microbial load and safety of Ethiopian paper currencies collected from street food vendors, hotels and cafeterias in Jimma town, southwest Ethiopia.

\section{Methods}

\section{Sample collection}

The study was conducted in Jimma town which is located at $353 \mathrm{~km}$ southwest of Addis Ababa, the capital city of Ethiopia. A total of hundred (100) paper currency samples currently in circulation involving five denominations $(1,5,10,50$ and 100), 20 notes each, were randomly collected from street food venders, workers of hotels and cafeterias in Jimma town. In addition, 20 newly minted paper currencies, obtained from Commercial Bank of Ethiopia, Jimma Branch were used as negative control. The samples were collected aseptically by letting the individuals to drop the paper currencies into a sterile polythene bags. The polythene bags were promptly sealed and the individuals were given a replacement equivalent to what they deposited in the polythene bags. The polythene bags were immediately transported to Jimma University, Research and Postgraduate Studies Laboratory for microbial analysis. Thereafter, a sterile cotton swab moistened with buffered peptone water solution was used for swabbing thoroughly on both surfaces of each sampled paper currency placed on pre-sterilized aluminum foil that was larger than the size of paper currencies and the swabs were separately soaked into $10 \mathrm{ml}$ sterile buffered peptone water solution. The samples were kept in refrigerator at $4^{\circ} \mathrm{C}$ until microbial analysis was conducted within one to two hours.

\section{Microbiological methods}

The collected paper currency samples were analyzed for microbial load and safety. Accordingly, $1 \mathrm{ml}$ of each paper currency swab sample was transferred aseptically into $9 \mathrm{ml}$ of buffered peptone water (BPW) and thoroughly mixed using vortex. The homogenates were serially diluted from $10^{-1}$ to $10^{-6}$ and a volume of $0.1 \mathrm{ml}$ aliquot of appropriate dilution was spread-plated in duplicate on pre-solidified plates of Plate Count Agar (Oxoid), MacConkey Agar (Oxoid), Violet Red Bile Agar (Oxoid), Mannitol Salt Agar (Oxoid) and Potato Dextrose Agar (Oxoid) plates supplemented with $0.1 \mathrm{~g}$ chloramphenicol and incubated at optimum temperature and time for counts of aerobic mesophilic bacteria and aerobic bacterial spore, Enterobacteriaceae, coliforms, staphylococci, yeasts and moulds, respectively. Plates with colonies between 30 and 300 were considered for counting. Both lactose fermenting pink to purple mucoid colonies and non-lactose fermenting colorless colonies on MacConkey agar were enumerated as member of Enterobacteriaceae. Purplish red colonies surrounded by reddish zone of precipitated bile on VRBA agar were counted as coliforms while formations of golden yellow colonies on mannitol salt agar were counted as staphylococci. Smooth (nonhairy) colonies without extension at periphery were counted as yeasts whereas hairy colonies with extension at periphery were counted as moulds. The counted colonies (mean values of duplicate plates) were expressed in colony forming units per square centimeter $\left(\mathrm{CFU} / \mathrm{cm}^{2}\right)$ of the sampled paper currencies and then converted into log colony forming units $\left(\log \mathrm{CFU} / \mathrm{cm}^{2}\right)$ for data management.

\section{Microbial analysis}

After enumeration of aerobic mesophilic bacteria, 10 to 15 colonies with distinct morphological differences like color, size and shape were randomly picked from countable plates and aseptically transferred into tubes containing $5 \mathrm{ml}$ Nutrient Broth (Oxoid). These were incubated at $30-35^{\circ} \mathrm{C}$ over night. Cultures were purified by repeated 
plating and preserved on Nutrient agar slants at $4^{\circ} \mathrm{C}$ until characterization was carried out. Then isolates were characterized to the genus level and various bacterial groups according to John [17] bacterial identification method. Accordingly, isolates were characterized for cell morphology (cell shape, cell grouping), motility, Gram reaction, O/F test (Oxidative or fermentative utilization of glucose), catalase test and cytochrome oxidase test. Furthermore, for identification of presumptive Staphylococcus aureus and Salmonella spp., the distinct colonies were purified and characterized using standard microbiological methods $[18,19]$. Accordingly, Gram-positive cocci with clustered arrangement under microscope were considered staphylococci and subjected to further biochemical tests (including catalase, cytochrome oxidase, and coagulase tests). Catalase test was carried out by flooding young colonies with a $3 \%$ solution of hydrogen peroxide $\left(\mathrm{H}_{2} \mathrm{O}_{2}\right)$. The formations of bubbles were considered as the presence of catalase. Furtermore, cytochrome oxidase test was conducted using the method out lined by Kovacs [20]. Briefly, freshly prepared $1 \% \alpha$ naphthalene in absolute ethanol and $1 \%$ $\mathrm{N}, \mathrm{N}$, - dimethyl - p- phenylenediammonium chloride in distilled water were mixed in the ratio of 2:3 just before use. After flooding the young colonies with the mixture on Nutrient Agar plates, appearance of a blue color on the colonies within 30 seconds to 2 minutes were considered as an oxidase positive reaction and negative when color is not changed. For identification of $S$. aureus, slide coagulase test was done. In slide test, which detects bound coagulase, colonies of the purified isolates were emulsified in a drop of distilled water on two separate slides to make thick suspensions. A loopful of plasma was added to one of the suspensions and mixed gently. Observation of the clumping within 5-10 seconds was considered that the organism was coagulase producer. In general, isolates that were Gram-positive, coccoid, catalase positive and capable of coagulating human plasma were considered as S. aureus.

For isolation of Salmonella spp., cotton swab sample of each paper currency was aseptically transferred into test tube containing $10 \mathrm{ml}$ of buffer peptone water (BPW), homogenized for 5 minutes and then incubated at $37^{\circ} \mathrm{C}$ for 24 hours (for recovery and proliferation of cells which might be injured during processing in addition to making the number of target organisms grow to a detectable level). Following the primary enrichment in buffer peptone water, $1 \mathrm{ml}$ of the culture was transferred onto $10 \mathrm{ml}$ of Selenite cysteine broth (Oxoid) and incubated at $43^{\circ} \mathrm{C}$ for 48 hours (to inhibit the growth of none targeted microorganisms like gram positive bacteria and Coliforms besides further enrichment of Salmonella spp.). A loopful of culture from Selenite cysteine broth was streaked onto Xylose Lysine Deoxycholate (XLD) agar (Oxoid) and incubated at $37^{\circ} \mathrm{C}$ for 18 hours. Characteristic colonies were picked, further purified and tested biochemically using gallery of biochemical media (all Oxoid) including Triple Sugar Iron Agar (TSIA), Lysine Iron Agar (LIA), Urea Agar (UA), Simmon's Citrate Agar (SCA) and Sulfide Indole Motility (SIM) medium [21].

\section{Growth potential of Staphylococcus aureus and Salmonella spp. isolated from paper currencies on selected weaning foods}

The growth potential of Staphylococcus aureus and Salmonella spp. was assessed on selected weaning foods (cow milk and mango juice). Selection of the weaning foods was based on the frequency of use of the same products in the study area, especially by out-patients and guardians visiting the referral hospital in the town. Two hundred (200) ml of each food items was separately homogenized using vortex and steamed at $80^{\circ} \mathrm{C}$ in water bath for 10 minutes to kill any vegetative cells that might be present in the food items. About $100 \mathrm{ml}$ of each food items was challenged separately with $1 \mathrm{ml}$ overnight cultures of the test strains to bring the final inoculums size

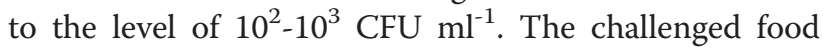
was incubated at $30-32^{\circ} \mathrm{C}$ for 24 hours. To determine the initial inoculum level, $10 \mathrm{ml}$ of each inoculated food was homogenized in $90 \mathrm{ml}$ of BPW and $0.1 \mathrm{ml}$ of appropriate dilution was spread plated on XLD for Salmonella spp. and MSA for S. aureus. A portion of food sample was further sampled aseptically at 6 hours interval from 0-24 hours [22]. The $\mathrm{pH}$ of each food sample was measured using digital $\mathrm{pH}$ meter from 0 to 24 hours at an interval of 6 hours while assessing the growth potential of the potentially pathogenic test stains.

\section{Statistical methods}

Data was analyzed using SPSS software version 16. All values were expressed as mean \pm standard deviation and the mean values of paper currency samples from different sources were compared using one way ANOVA and the significance of differences was considered at $95 \%$ confidence interval $(p<0.05)$.

\section{Results}

The mean counts of aerobic mesophilic bacteria (AMB), staphylococci and Enterobacteriaceae were the highest in paper currency samples of denomination ten (7.68, 6.32, and $5 \log \mathrm{CFU} / \mathrm{cm}^{2}$, respectively) followed by denomination one $\left(7.65,6.03\right.$ and $\left.4.13 \mathrm{log} \mathrm{CFU} / \mathrm{cm}^{2}\right)$, respectively, (Table 1). The lowest mean count was encountered in samples from denomination hundred with the least mean counts of AMB (4.66 log CFU/ $\mathrm{cm}^{2}$ ) and below detectable level for all the rest except for aerobic spore former $\left(2.28 \log \mathrm{CFU} / \mathrm{cm}^{2}\right)$. Likewise, the mean counts $\left(\log \mathrm{CFU} / \mathrm{cm}^{2}\right)$ of coliforms were the highest in paper currency denomination one (4.41) (Table 1) followed by 
Table 1 Mean microbial counts $\left(\log \mathrm{CFU} / \mathrm{cm}^{2}\right)$ of microbial groups isolated from paper currencies in Jimma town, southwest Ethiopia

\begin{tabular}{lcccccccc}
\hline PCD & $\begin{array}{c}\text { Sample } \\
\text { size }\end{array}$ & $\begin{array}{c}\text { AMB } \\
\text { Mean } \pm \text { SD }\end{array}$ & $\begin{array}{c}\text { Staph. } \\
\text { Mean } \pm \text { SD }\end{array}$ & $\begin{array}{c}\text { Enterob. } \\
\text { Mean } \pm \text { SD }\end{array}$ & $\begin{array}{c}\text { Coliforms } \\
\text { Mean } \pm \text { SD }\end{array}$ & $\begin{array}{c}\text { ABS } \\
\text { Mean } \pm \text { SD }\end{array}$ & $\begin{array}{c}\text { Yeasts } \\
\text { Mean } \pm \text { SD }\end{array}$ & $\begin{array}{c}\text { Molds } \\
\text { Mean } \pm \text { SD }\end{array}$ \\
\hline 1 & 20 & $7.65 \pm 0.53^{\mathrm{a}}$ & $6.03 \pm 3.14^{\mathrm{c}}$ & $4.13 \pm 3.47^{\mathrm{e}}$ & $4.41 \pm 3.00^{\mathrm{g}}$ & $5.06 \pm 3.45^{\mathrm{i}}$ & $0.89 \pm 1.24^{\mathrm{k}}$ & $0.51 \pm 1.05^{\mathrm{m}}$ \\
5 & 20 & $6.83 \pm 0.96^{\mathrm{a}}$ & $4.90 \pm 3.72^{\mathrm{c}}$ & $3.25 \pm 2.38^{\mathrm{e}}$ & $3.26 \pm 2.35^{\mathrm{g}}$ & $3.65 \pm 2.77^{\mathrm{i}}$ & $0.25 \pm 0.78^{\mathrm{k}}$ & $0.25 \pm 0.76^{\mathrm{m}}$ \\
10 & 20 & $7.68 \pm 0.59^{\mathrm{b}}$ & $6.31 \pm 3.26^{\mathrm{c}}$ & $5.00 \pm 3.37^{\mathrm{e}}$ & $4.09 \pm 3.44^{\mathrm{g}}$ & $5.24 \pm 3.17^{\mathrm{i}}$ & $0.63 \pm 1.12^{\mathrm{l}}$ & $0.38 \pm 0.93^{\mathrm{m}}$ \\
50 & 20 & $4.72 \pm 0.11^{\mathrm{a}}$ & $2.78 \pm 2.11^{\mathrm{d}}$ & $1.69 \pm 1.37^{\mathrm{f}}$ & $1.64 \pm 1.29^{\mathrm{h}}$ & $2.69 \pm 2.19^{\mathrm{j}}$ & $0.26 \pm 0.77^{\mathrm{k}}$ & $0.12 \pm 0.55^{\mathrm{m}}$ \\
100 & 20 & $4.66 \pm 0.07^{\mathrm{a}}$ & $1.83 \pm 1.19^{\mathrm{d}}$ & $1.64 \pm 1.30^{\mathrm{f}}$ & $1.52 \pm 1.15^{\mathrm{h}}$ & $2.28 \pm 2.08^{\mathrm{j}}$ & $0.25 \pm 0.76^{\mathrm{k}}$ & $0.13 \pm 0.56^{\mathrm{m}}$ \\
Total & 100 & $6.32 \pm 0.45$ & $4.43 \pm 2.68$ & $3.14 \pm 2.25$ & $2.98 \pm 2.25$ & $3.78 \pm 2.73$ & $0.46 \pm 0.94$ & $0.28 \pm 0.77$
\end{tabular}

Where: $\mathrm{PCD}=$ Paper Currency Denominations, $\mathrm{AMB}=$ Aerobic Mesophilic Bacteria, Staph. = Staphylococci, Enterob. = Enterobacteriaceae, ABS = Aerobic Bacterial Spore, $S D=$ Standard deviation. Similar superscripts within the same column indicate absence statistically significant differences among the mean values. Mean with different superscript is statistically significant from the others.

denomination ten (4.09). But, mean counts of yeasts and molds in all paper currency samples were below detectable levels $\left(<2 \log \mathrm{CFU} / \mathrm{cm}^{2}\right)$ even on plates inoculated from the original suspension (Table 1). Generally, the mean counts of all bacterial groups were above detectable level $\left(\geq 2 \log \mathrm{cfu} / \mathrm{m}^{2}\right)$ in all paper currency samples although the mean counts of Staphylococci (denominator 100) and Enterobacteriaceae and coliforms (denominators 50 and 100) were below detectable levels (Table 1). The maximum mean bacterial count encountered among the paper currency samples was $7.68 \pm 0.59 \mathrm{CFU} / \mathrm{cm}^{2}$ for AMB (in denomination five). There were statistically significant differences among the mean counts of AMB, staphylococci, Enterobacteriacea, coliforms, aerobic spore counts and yeast of the different denominations except for yeast counts (Table 1). The twenty newly mint currency notes used as least negative controls did not reveal any microorganism.

\section{Microbial analysis of paper currencies}

From a total of 100 different paper currency samples analyzed for the microbiological safety, a total of 222, 204, 228, 174 and 135 bacterial colony were isolated from among paper currency denomination 1, 5, 10, 50 and
100, respectively (Table 2). Overall, 963 bacterial isolates were obtained, characterized and grouped into a family and six genera. Out of 963 isolates, 814 (84.53\%) were Gram positive and 149 (15.47\%) were Gram negative bacteria (Table 2). The aerobic mesophilic bacterial count were dominated by Staphylococcus spp. 328 (34.06\%) followed by Bacillus spp. 307 (31.88\%) and Enterobacteraceae 129 (13.39\%) (Table 2). Micrococcus spp. 92 (9.55\%), Streptococcus spp. 87 (9.03\%), Acinetobacter spp. 14(1.45\%) and Pseudomonas spp. 6(0.62\%) were also among the aerobic mesophilic bacteria encountered on paper currency samples.

\section{Prevalence of Staphylococcus aureus and Salmonella spp}

In the present study, of the total 100 paper currency samples, $25 \%$ were positive for S. aureus (Table 3). It was as prevalent as $10 \%$ in paper currency denomination one and $8 \%, 4 \%, 2 \%$ and $1 \%$ in denomination ten, five, fifty and hundred, respectively (Table 3). On the other hand, $10 \%$ of the samples were positive for Salmonella spp. The prevalence of Salmonella spp. was higher in paper currency denomination ten $(5 \%)$ followed by denomination one (3\%). The frequency distribution of Salmonella spp. in both denominations five and fifty were

Table 2 Frequency distribution (\%) of dominant bacteria isolated from paper currencies collected from food vendors, Jimma town, Southwest Ethiopia

\begin{tabular}{|c|c|c|c|c|c|c|c|c|c|}
\hline$\overline{P C D}$ & $\begin{array}{l}\text { No of } \\
\text { PCD }\end{array}$ & $\begin{array}{c}\text { No of } \\
\text { isolates } \\
\text { No }\end{array}$ & $\begin{array}{c}\text { Staphylococcus } \\
\text { spp. } \\
\text { Frequency } \\
(\%)\end{array}$ & $\begin{array}{l}\text { Bacillus } \\
\text { spp. } \\
\text { Frequency } \\
(\%)\end{array}$ & $\begin{array}{c}\text { Enterobacteriaceae } \\
\text { Frequency } \\
(\%)\end{array}$ & $\begin{array}{l}\text { Micrococcus } \\
\text { spp. } \\
\text { Frequency } \\
(\%)\end{array}$ & $\begin{array}{c}\text { Streptococcus } \\
\text { sp. } \\
\text { Frequency } \\
(\%)\end{array}$ & $\begin{array}{c}\text { Acinetobacter } \\
\text { spp. } \\
\text { Frequency } \\
(\%)\end{array}$ & $\begin{array}{c}\text { Pseudomonas } \\
\text { spp. } \\
\text { Frequency } \\
(\%)\end{array}$ \\
\hline 1 & 20 & 222 & $71(31.98)$ & $70(31.53)$ & $25(11.26)$ & $26(11.71)$ & $22(9.90)$ & $5(2.25)$ & $3(1.35)$ \\
\hline 5 & 20 & 204 & $67(32.84)$ & $60(29.41)$ & $40(19.61)$ & $14(6.86)$ & $20(9.80)$ & $3(1.47)$ & - \\
\hline 10 & 20 & 228 & $72(31.58)$ & 79 (34.65) & $29(12.72)$ & $21(9.21)$ & $20(8.77)$ & $4(1.75)$ & $3(1.32)$ \\
\hline 50 & 20 & 174 & $62(35.63)$ & $57(32.76)$ & $20(11.49)$ & $18(10.34)$ & $15(8.62)$ & $2(1.15)$ & - \\
\hline 100 & 20 & 135 & $56(42.24)$ & $41(29.31)$ & $15(11.21)$ & $13(9.48)$ & $10(7.76)$ & - & - \\
\hline Total & 100 & 963 & $328(34.06)$ & 307 (31.88) & 129 (13.39) & $92(9.55)$ & $87(9.03)$ & $14(1.45)$ & $6(0.62)$ \\
\hline
\end{tabular}

Where; $P C D=$ Paper Currency Denominations. Numbers in parenthesis indicate percentage. 
Table 3 Prevalence of S. aureus and Salmonella spp. in paper currencies in Jimma town, southwest Ethiopia

\begin{tabular}{cccc}
$\begin{array}{c}\text { Paper } \\
\text { currency } \\
\text { denomination }\end{array}$ & $\begin{array}{c}\text { Sample } \\
\text { size }\end{array}$ & $\begin{array}{c}\text { No S. aureuspositive } \\
\text { samples (\%) } \\
\text { Frequency (\%) }\end{array}$ & $\begin{array}{c}\text { No Salmonella spp. } \\
\text { positive samples (\%) } \\
\text { Frequency (\%) }\end{array}$ \\
\hline 1 & 20 & $10(10)$ & $3(3.0)$ \\
5 & 20 & $4(4.0)$ & $1(1.0)$ \\
10 & 20 & $8(8.0)$ & $5(5.0)$ \\
50 & 20 & $3(2.0)$ & $1(1.0)$ \\
100 & 20 & $1(1.0)$ & $0(0.0)$ \\
Total & 100 & $25(25.0)$ & $10(10.0)$ \\
\hline
\end{tabular}

Numbers in parenthesis indicate percentage.

equal (1\%). However, Salmonella spp. was not detected from denomination hundred (Table 3).

The growth potential of Salmonella sp. and Staphylococcus aureus in selected weaning foods

The count of Salmonella sp. in each food samples ranged from $2.8-3 \log \mathrm{CFU} \mathrm{ml} \mathrm{m}^{-1}$ at 0 hour (Figure 1). Salmonella spp. were observed growing fast in milk (4.7 $\log$ CFU ml-1) as compared to its growth in juice (4.2 $\log$ CFU ml-1) at 6 hours. The count increased by 1.8

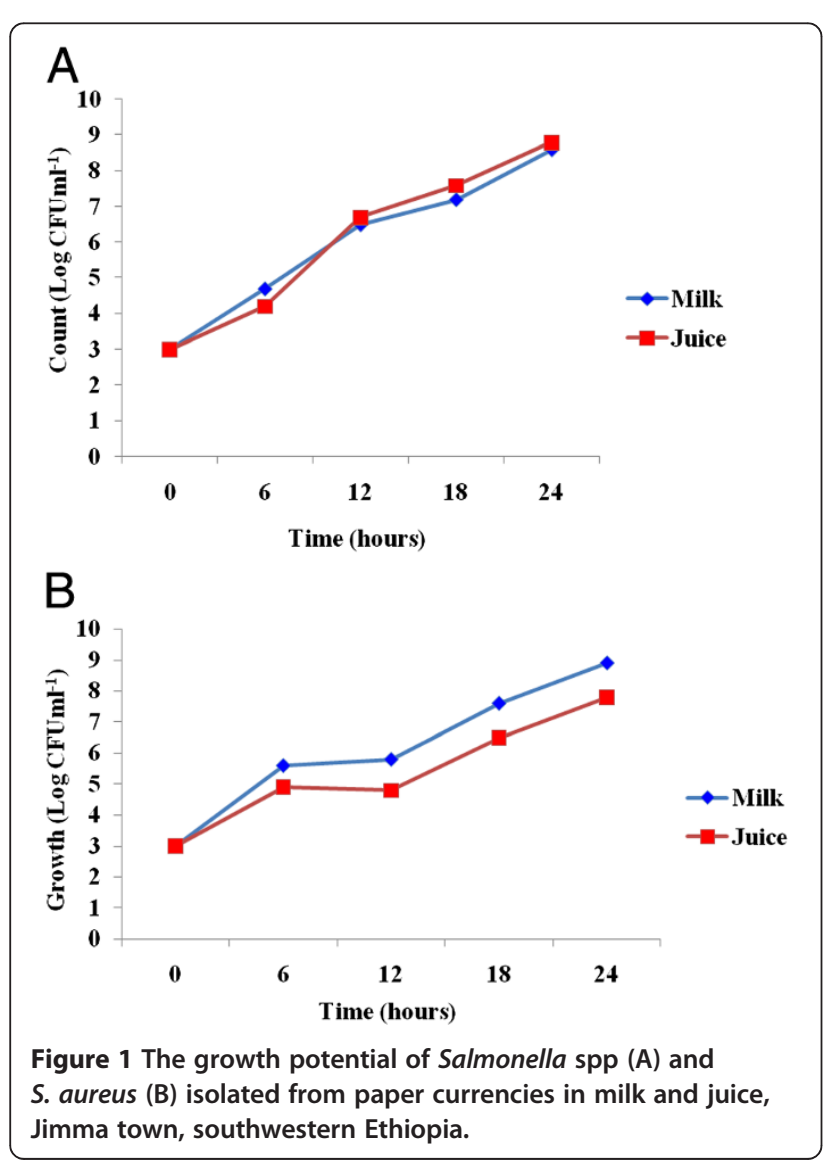

$\log$ CFU ml ${ }^{-1}$ and $2.5 \log$ CFU ml ${ }^{-1}$ in milk and juice, respectively, during the first 6 hours (Figure 1). Thereafter, the count reached $6.5 \log \mathrm{CFU} \mathrm{m}{ }^{-1}$ in milk and $6.7 \mathrm{log}$ CFU ml $\mathrm{m}^{-1}$ ) in juice within 12 hours. The maximum growths attained were $8.6 \log \mathrm{CFU} \mathrm{m} \mathrm{m}^{-1}$ (milk) and 8.8 $\log$ CFU ml ${ }^{-1}$ (juice) at 24 hours (Figure 1 ).

Likewise, the growth potential of $S$. aureus isolated from paper currencies was assessed. Accordingly, higher growth rate was observed in milk (5.6 log CFU ml-1) than in juice (4.9 $\log \mathrm{CFU} \mathrm{ml} \mathrm{m}^{-1}$ ) at the first 6 hours (Figure 1). The growth rate was slower during the second 6 hours duration as compared to the first 6 hours in juice (4.8 $\log \mathrm{CFU} \mathrm{ml} \mathrm{m}^{-1}$ ) and slight increase was observed in milk $\left(5.8 \log \mathrm{CFU} \mathrm{ml} \mathrm{m}^{-1}\right)$. The counts increased by 2.2 $\log$ in milk (5.8 to $7.6 \log \mathrm{CFU} \mathrm{ml} \mathrm{m}^{-1}$ ) and $1.7 \mathrm{log}$ in juice (4.8 to $6.5 \log \mathrm{CFU} \mathrm{ml} \mathrm{m}^{-1}$ ) at 18 hours. Only slighter growth pattern $(1.3 \mathrm{log})$ was observed in both food samples (7.6 to $8.9 \log$ CFU ml ${ }^{-1}$ in milk and 6.5 to $7.8 \mathrm{log}$ CFU ml ${ }^{-1}$ in juice) at 24 hours (Figure 1 ).

The $\mathrm{pH}$ values of both food samples challenged with Salmonella sp. were 6.92 (milk) and 3.83 (juice) at 0 hours (Figure 2). There was initial rise in $\mathrm{pH}$ from 6.92 to 6.96 (in milk) and 3.83 to 3.98 (in juice) at 6 hours. However, the $\mathrm{pH}$ values dropped in both food samples by more than 0.5 (from 6.96 to 6.82 in milk and

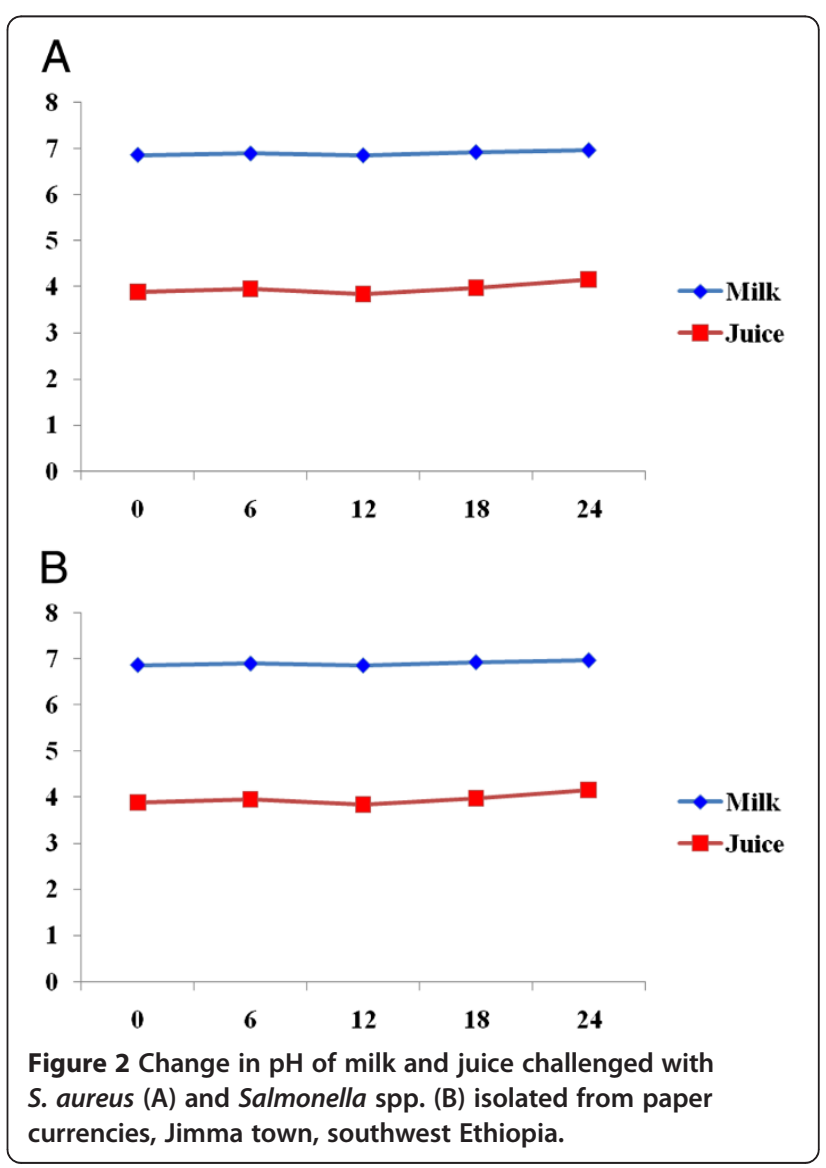


3.98 to 3.92 in juice) at 12 hours. Nevertheless, it was raised afterwards up to 24 hours (Figure 2).

The $\mathrm{pH}$ values of both food samples challenged by the two pathogens showed some variability in due course of fermentation. However, the overall patterns were gradual increase in $\mathrm{pH}$ with drop in degree of acidification mainly due to depletion of carbohydrate sources and reversion towards utilization of proteins and/or release of other metabolites during the 24 hours period (Figure 2).

\section{Discussion}

According to WHO [23], food handling personnel play an important role in ensuring food safety throughout the chain of food production, processing, storage and preparation. Mishandling and disregarding of hygienic measures on the part of food vendors may enable pathogens to get access to food and in some cases to survive and multiply in sufficient numbers to cause illness to the consumers [24]. Consequently, the combination of the widespread use of paper currencies and their constant exchange make them a likely agent for various disease transmissions since communicable diseases can spread through contact with fomites. Besides, a study revealed that paper currencies can serve as an ideal breeding ground for microorganisms [25].

All 100 paper currency samples evaluated in present study were contaminated with different microbial groups. In agreement to several studies [26-32], the predominant bacteria encountered among aerobic mesophilic bacteria in this study were Staphylococcus spp. (34.06\%) followed by Bacillus spp. (31.88\%), and Enterobacteraceae (13.39\%).

Different studies indicated that the denomination of paper currencies have a direct correlation with degree of contamination as lower denomination notes had the most contaminants [29,32-34]. Accordingly, the present study showed that lower denomination of Ethiopian paper currencies (1, 5 and 10 notes) had higher degree of contamination with various microorganisms than upper denominations (50 and 100 notes). Thus, from the above fact it can be inferred that lower denomination notes harbor the highest load of microbes, probably because they are exchanged more frequently from one hand to another during market transactions than the higher denomination notes. Moreover, survey conducted elsewhere on mint paper currencies not in circulation were negative for bacterial isolates $[13,35]$. In agreement to these report, our study also showed all 20 new paper currency samples not in circulation were negative for bacterial isolates.

Generally, the high mean counts of Enterobacteriaceae on surface swab samples in the present study reveal the poor sanitary condition and poor hygienic practices exercised by those who use the currencies. In addition, coliforms may be introduced to paper currencies by several means; but their presence indicates lack of proper hand washing practice after using toilet. Besides, as Pomperayer and Gaylarde [36] reported, paper currencies are in permanent movement, passing in all environments that constitute a reservoir and source of various bacteria including pathogenic Escherichia coli, which can survive 11 days on the inert surfaces of utilities. Therefore, handling of paper currencies may constitute another risk factor for contamination of ready to eat foods unless good hygienic practices are exercised [37].

Staphylococcus spp. are found ubiquitously distributed in environment and strains present in the nose often contaminate hands, fingers, faces, and nasal carriers which can easily become skin carriers [38]. Thus, the presence of Staphylococcus species on paper currencies could be due to rubbing off or may be surfing from a skin flake [4].

Regarding the prevalence Staphylococcus aureus, 25\% of the entire paper currency samples in the present study were positive for this bacterium. Our finding is in agreement with earlier reports $[4,29,39]$. In view of the fact that $S$. aureus lives and flourishes in the human nose, throat and skin; the likelihood of frequent recontamination of paper currencies is quite high when good hygienic practices are not in place [40].

In the present study, the prevalence of Salmonella spp. was $10 \%$. In other report, too, Salmonella spp. were detected in $15 \%$ of paper currencies examined from Bangladesh [4]. Moreover, Orukotan and Yabaya [41] reported $4.65 \%$ prevalence of Salmonella spp. in paper currency samples collected from Iran. The detection of Salmonella spp. on paper currency could suggest faecal contamination of the paper currencies following poor hygienic practice, potentially resulting in communityacquired infections and disease outbreaks [42]. Moreover, Salmonella spp. have marked importance in food borne diseases worldwide [43] besides its capacity to persist on inanimate surfaces for days (up to months) by forming biofilm [44].

The challenge studies showed that the inoculated Salmonella spp. reached the level of infective dose $(\geq 5 \mathrm{log}$ $\mathrm{CFU} \mathrm{ml}{ }^{-1}$ ) in cow milk and mango juice within 12 hours. The maximum count obtained was $8.6 \log \mathrm{CFUml}^{-1}$ (milk) and $8.8 \log \mathrm{CFU} \mathrm{m}{ }^{-1}$ (juice) within 24 hours. The observation of the present study was in agreement with the earlier findings of Muleta and Ashenafi [22] where the counts of Salmonella spp. were $>\log 8 \mathrm{CFUg}^{-1}$ within 24 hours in 'kitfo' and egg sandwich. On the other hand, Erku and Ashenafi [45] evaluated the growth potential of Salmonella spp. in weaning food in Addis Ababa, Ethiopia, where the counts of Salmonella reached values as high as $\log 8 \mathrm{CFU} \mathrm{ml}{ }^{-1}$ within 12 hours. Thus, based on the current observation, it could be considered 
that ingestion of foods contaminated with sufficient number of Salmonella could induce disease symptoms such as diarrhea, vomiting and fever within the indicated incubation hours [46].

In the present study, the growth potential of S. aureus increased considerably in milk with decrease in juice at 12 hours and reached the infective dose within 18 hours in both food samples. The minimum infective dose for S. aureus is $6 \log$ CFU g ${ }^{-1}$ [47]. However, Muleta and Ashenafi [22] reported that $S$. aureus reached infective dose in all food samples (macaroni, lentil sandwich and egg sandwich) within 12 hours of initial incubation. In the current study, the maximum count of $S$. aureus recorded within 24 hours was $8.9 \log$ CFU ml ${ }^{-1}$ (milk samples) followed by $7.8 \mathrm{CFUml}^{-1}$ (juice samples). Toxin production is initiated when the $S$. aureus populations exceed $10^{6} \mathrm{CFUg}^{-1}$ [48].

In the current study, growth of challenged pathogens generally increased with increase in $\mathrm{pH}$ after a period of adaptation and/or modification of the medium. The change in $\mathrm{pH}$ with time could be due to the change of source of carbon and nitrogen. Some microbial cultures generate enzymes to utilize a new carbon and energy substrate when a small amount of the original carbon and energy substrate is present [49-51]. However, optimum $\mathrm{pH}$ is not the only requirement for the growth of microorganisms as there could be an interplay of both intrinsic and extrinsic parameters that determines the survival and growth of microorganisms in a medium [52].

In general, the current study revealed that paper currencies harbor diverse groups of microorganisms, some of which are potential pathogens. Thus, it calls for awareness development at all levels, especially among personnel working in food establishments, on the possible health risks associated with poor handling of paper currencies while serving/preparing foods. In fact, it should be the concern of all individuals who handle paper money in a circulation directly or indirectly.

Although this study was the first of its kind from Ethiopia, sample collection was delimited to Jimma town. Had the sample collection involved many parts of the country by considering the cultural diversity, hence differences in techniques of food preparation, handling and serving, it would have further strengthened the current findings. Furthermore, the characterization of isolates didn't involve molecular techniques for much better identification of the same to species and subspecies level. Despite these limitations, the current study generated valuable data to be used for immediate intervention besides serving as a baseline for further study.

\section{Conclusions}

All paper currencies evaluated in this study were contaminated with different microbes including potentially pathogenic Salmonella spp. and S. aureus. The presence of high number of pathogenic bacteria could cause foodborne diseases of different types including typhoid fever and food poisoning. Moreover, lower denominations which are frequently used by public were more contaminated with various microorganisms than higher denominations. In addition, pathogenic test strains isolated from paper currencies were found growing to infective dose within 12-18 hours indicating that paper currencies are among the risk factors to human health. Thus, periodic evaluation of microbial safety of paper currencies are recommended besides frequent awareness development efforts to improve the existing poor hygienic practices being exercised while handling paper currencies. The government of Ethiopia could also assess the possibility of introducing washable plastic paper currencies to make the cleaning possible without compromising the life spans of paper money in the circulation.

\section{Competing interest}

The authors declared that they have no competing interest.

\section{Authors' contributions}

GG was fully involved in all phases of the study: research design, data collection and monitoring in laboratory, data analysis, interpretation, and write-up of the manuscript; TK and KB involved in designing of the study project, supervised the research and critically revised the manuscript for publication. All authors read and approved the final manuscript.

\section{Acknowledgment}

The authors would like to thank the study participants for their willingness to participate in the study. Furthermore, College of Natural Sciences and Department of Biology are acknowledged for facilitation of the laboratory spaces and provision of basic research facilities. The work was financially supported by Jimma University.

Received: 23 July 2014 Accepted: 18 November 2014

Published: 25 November 2014

\section{References}

1. Bernholtz P: Monetary Regimes and Inflation: History, Economic and Political Relationships. Basle, Switzerland: Edward Elgar Publishing; 2003.

2. Igumbor EO, Obi CL, Bessong PO, Potgiester N, Mkasi TC: Microbiological analysis of banknotes circulating in the Venda region of Limpopo province, South Africa. Sabinet. 2007, 103:365-366.

3. Debajit B, Pratap P, Tarun K: Paper currencies, a potential carrier of pathogenic microorganisms. Int J Appl Biol Pharm Technol 2012, 3:23-25.

4. Ahmed PS, Nasreen T, Feroza B: Evaluation of the microbial contamination of Bangladesh paper currency notes (Taka) in circulation. Adva BiolRes 2010, 4:266-271.

5. Mensah P, Yeboah-Manu D, Owusu-Darko K, Ablordey A: Street foods in Accra, Ghana: how safe are they? Bull World Heal Organ 2002, 80:546-554.

6. Brady G, Kelly J: The assessment of the public health risk associated with the simultaneous handling of food and money in the food industry. In Report of Central Goldfields Money Survey. Central Goldfields Shire Council. Dunn: Son and Stone; 2000:1-10.

7. FSH (Food Safety and Hygiene): Money handling in food science operations. In A bulletin for the Australian Food Industry, February; 2000. Accessible at http://www.foodscience.csiro.au/fshbull/fshbull20c.htm Retrieved on 20 June, 2014

8. Michaels B: Handling money and serving ready-to-eat food. Food Serv Technol 2002, 2:1-3.

9. Chukuezi CO: Food safety and hygienic practices of street food vendors in Owerri, Nigeria. Stud Socio/ Sci 2010, 1:50-57.

10. Green L, Selman C, Radke V: Food worker hand washing practices: an observational study. J Food Protect 2006, 69:2417-2426. 
11. Awe S, Eniola KIT, Ojo FT, Sani A: Bacteriological quality of some Nigerian currencies in circulation. Afr J Microbiol Res 2010, 4:2231-2234.

12. Charnock C: Swabbing of waiting rooms magazines reveals only low levels of bacterial contamination. Brit. J. Gen. Pract. 2005, 55:147-148.

13. Lamichhane J, Adhikary S, Gautam P, Maharjan R, Dhakal B: Risk of handling paper currency in circulation chances of potential bacterial transmittance. Nepal J Sci Technol 2009, 10:161-166.

14. Alwakeel SS, Nasser L: Bacterial and fungal contamination of Saudi Arabian paper currency and cell phones. Asian J. Biological Sci. 2011, 4:556-562.

15. Awodi NO, Nock IH, Aken'Ova I: Prevalence and public health significance of parasite cysts and eggs on the Nigerian money. Nig J Parasitol 2000, 9:91-94.

16. Prasai T, Yami KD, Joshi DR: Microbial load on paper/polymer money and coins. Nepal J Sci Tech 2008, 9:105-109.

17. John L: An introduction to bacterial identification. 2012, http://www. jlindquist.net/generalmicro/102bactid.html. Last accessed march 27th 2014

18. Acco M, Ferreira FS, Henriques JA, Tondo EC: Identification of multiple strains of Staphyloccocus aureus colonizing nasal mucosa of food handlers. Food Microbiol 2003, 20:489-493.

19. Johnson TR, Case CL: Laboratory Experiments in Microbiology. 8th edition. San Francisco: Pearson Education; 2007.

20. Kovacs N: Identification of Pseudomonas pyocyanae by the oxidase reaction. Nature. 1956, 178:703.

21. Arvanitidou MA, Tsakris D, Sofianou R, Katsouyannopoulos V: Antimicrobial resistance and R-factor transfer of Salmonella isolated from chicken carcasses in Greek hospitals. Int J Food Micro 1998, 40:187-201.

22. Muleta D, Ashenafi M: Salmonella, Shigella and growth potential of other food borne pathogens in Ethiopia street vended foods. East Afr Med J 2001, 78:576-580.

23. WHO: Health surveillance and management procedures for food handling personnel. Geneva: WHO technical report series, WHO; 1980:785-852.

24. Muinde OK, Kuria E: Hygienic and sanitary practices of vendors of street foods in Nairobi, Kenya. Afr J Food Agr Nutr Develop 2005, 5:1-15.

25. Ayandele AA, Adeniyi SA: Prevalence and antimicrobial resistance pattern of microorganisms isolated from Naira notes in Nigeria. Nig J Res Biol 2011, 8:587-593

26. Adamu J, Jairus Y, Ameh J: Bacterial contaminant of Nigerian currency notes and associated risk factors. Res J Med Sci 2012, 6:1-6.

27. Neel R: Isolation of pathogenic microorganisms from contaminated paper currency notes in circulation from different market places in Korogwe and Mombo towns in Tanzania. J. Microbiol Biotech Res 2012, 2:470-474.

28. Mohammed RK, Rajeswari KV, Nikhitha R, Reshma R, Santhosh K: Assessment of microbial contamination of Indian paper currency notes in circulation. Int J Recent Scient Res 2013, 4:1516-1518.

29. Moosavy MH, Shavisi N, Warriner K, Mostafavi E: Bacterial contamination of Iranian Paper Currency. Iranian J Publ Health 2013, 42:1067-1070.

30. Pal K, Das NS, Bhattacharya S: Bacteriological profile of Indian currency circulating in a tertiary care hospital in rural Bengal. JRRMS 2013, 3:23-27.

31. Kalpana S, Hemant M, Gaurav S: Microbial contamination of indian currency notes in Bhopal. J Evol Med Dent Sci 2014, 3:1379-1384.

32. Vriesekoop F, Russell C, Alvarez-Mayorga B: Dirty Money: an investigation into hygiene status of some of the world's currencies as obtained from food outlets. Foodborne Pathogens and Disease 2010, 7:1497-1502.

33. Hassan A, Farouk H, Hassanein F, Abdul-Ghani R: Currency as a potential environmental vehicle for transmitting parasites among food-related workers in Alexandria. Egypt Trans R Soc Trop Med Hyg 2011, 105:519-24.

34. Pradeep NV, Marulasiddaiah BS, Chetana M: Microbial contamination of Indian currency notes in circulation. J Res Biol 2012, 2:377-382.

35. Tagoe D, Baidoo S, Dadzie I, Ahator D: A study of bacterial contamination of ghanaian currency notes in circulation. Int J Microbiol 2009, 8:21-38.

36. Pomperayer RDM, Gaylarde CC: The influence of temperature on the adhesion of mixed culture of Staphylococcus aureus and Escherichia coli to propylene. J Food Microbiol 2000, 17:361-365

37. Barro N, Bello AR, Savadogo A: Hygenic status assessment of dish washing waters, utensils, hands and pieces of money from street food processing sites in Ouagadougou, Burkina Faso. Afr J Biotech 2006, 5:1107-1112.

38. Kumar JD, Negi YK, Gaur A, Khanna D: Detection of virulence genes in Staphylococcus aureus isolated from paper currency. Int J Infect Dis 2009, 13:450-455.
39. Umeh EU, Juluku JU, Ichor T: Microbial contamination of Naira (Nigerian Money) notes in circulation. Res J Environ Sci 2007, 1:336-339.

40. Ukwuru MU, Gabriel A: Cross contamination between food and money due to simultaneous handling. School of Technology, Federal Polytechnic, Idah, Kogi State, Nigeria. J App/ Sci Environ 2012, 3:42-48.

41. Orukotan AA, Yabaya A: Microbial contamination of naira notes in circulation within Kaduna Metropolis. J Med Appl Biosci 2011, 2:20-27.

42. Tagoe DNA, Nyarko H, Arthur SP, Birikorang EA: A study of antibiotic susceptibility pattern of bacteria isolates in sachet drinking water sold in the cape coast metropolis of Ghana. Res J Microbiol 2011, 6:453-458.

43. Shahram K, Gholamreza S: Determination of bacterial contamination isolated from Sandwiches in Kerman City and their resistance to commonly used antimicrobials. Archives of Applied Sci Res 2012, 4:1100-1105.

44. Kramer A, Schwebke I, Kampf G: How long do nosocomial pathogens persist on inanimate surfaces? A systematic review. BMC Infectious Diseases. 2006, 6:130-137.

45. Erku WA, Ashenafi M: Prevalence of food-borne pathogens and growth potential of Salmonella in weaning foods from Addis Ababa, Ethiopia. East Afr Medi J 1998, 75:215-218.

46. Feasey A, Dougan G, Robert A, Kingsley R, Heyderman S, Gordon A: Invasive non-typhoidal Salmonella disease: an emerging and neglected tropical disease in Africa. The Lancet 2012, 379:2489-2499.

47. Schelin J, Wallin-Carlquist N, Cohn MT, Lindqvist R, Barker GC, Radstrom P. The formation of Staphylococcus aureus enterotoxin in food environments and advances in risk assessment. Foodborne Infect 2011, 2:580-592.

48. Bennett RW, Monday SR: Staphylococcus aureus. In International Handbook of Foodborne Pathogens. Edited by Miliotis MD, Bier JW. New York: Marcel Dekker, Inc; 2003:151-165.

49. Don SM: Optimal Conditions for the Growth of E. coli. 2008th edition. 2008. www.scribd.com/doc/11337868/Optimal-Conditions-for-the-Growth-of-EColi. Last accessed April $12^{\text {th }} 2014$

50. Lee YK: Microbial biotechnology principles and applications. 2nd edition. Singapore: World Scientific Publishing Co. Pt. Ltd; 2011.

51. Tadesse G, Ashenafi M, Ephraim E: Survival of E. coli 0157:H7, Staphylococcus aureus, Shigella flexneri and Salmonella spp. in fermenting 'Borde', a traditional Ethiopian beverage. J Food Contr 2005, 16:189-196.

52. Jay JM, Loessner MJ, Golden DA: Modern food Microbiology. 7th edition. New York: Springer science + Business Media, Inc; 2005:233.

doi:10.1186/1756-0500-7-843

Cite this article as: Girma et al:: Microbial load and safety of paper currencies from some food vendors in Jimma Town, Southwest Ethiopia. BMC Research Notes 2014 7:843.

\section{Submit your next manuscript to BioMed Central and take full advantage of:}

- Convenient online submission

- Thorough peer review

- No space constraints or color figure charges

- Immediate publication on acceptance

- Inclusion in PubMed, CAS, Scopus and Google Scholar

- Research which is freely available for redistribution 